\title{
Knowledge Sharing Processes as Critical Enablers for Process Innovation
}

\author{
Sawasn J. Al-Husseini, Ibrahim M. Elbeltagi, and Talib A. Dosa
}

\begin{abstract}
The higher education sector today are facing global challenges from the rapid technological change and increased demands of today's world. Academic institutions need to develop their abilities and respond to these demands like business organisations. Knowledge and knowledge sharing are considered the main critical forces for business success and the key to enhancing innovation. Knowledge sharing is considered to be the foundation of learning and research at academic institutions and to play a key role in developing the innovation of universities.

This research seeks to examine the impact of knowledge sharing processes (donating and collecting) on process innovation. A total of 252 usable questionnaires were collected from public higher education institutions in Iraq. Structural equation modelling with AMOS 21 confirmed the importance of knowledge sharing in developing innovation in higher education. Guidelines are developed for academics as well as leaders, and evidence is provided in support of the use of knowledge sharing to enhance process innovation within higher education in developing countries, particularly Iraq.
\end{abstract}

Index Terms-Knowledge sharing, process innovation, higher education, structural equation modelling, developing countries.

\section{INTRODUCTION}

The higher education (HE) sector today are facing global challenges from the rapid technological change and increased demands of today's world [1]. Higher education institutions (HEIs) need to enhance their abilities and respond to these demands like other organisations [2]. Academic institutions are important because they are producers of innovation through the creation of products and services. They are playing a critical role in promoting and sustaining economic booms through their research, KS, and creation of a skilled graduate workforce [3]

Knowledge and knowledge sharing are recognized the most significant resource for innovation [4]. It can lead to better decision-making capabilities, and reduce product development cycle time [5]. KS increases the effectiveness of the organisation, and its creativity and reduces risk and costs [6]. It is the foundation of learning and research at universities and a vital pillar of KM that is critical to academic innovation

Manuscript received April 6, 2015; revised June 16, 2015

S. J. Al-Husseini is with the Middle Technical University, Institute of Administration Rusafa, Braq (e-mail: swasn.al-husseni@hotmial.com).

I. M. Elbeltagi is with the School of Management, University of Plymouth, UK (e-mail: i.elbeltagi@plymouth.ac.uk)

T. A. Dosa is with the Ministry of Immigration and Displacement, Office of Information and Researches, Baghdad, Iraq (e-mail: dosa.talib@yahoo.com).
[7].

Within developing countries like Iraq HE sector is also facing rapidly changing challenges that require innovation. The country is making great efforts to develop its human resources through education. The aim of its educational policy is to reorganise the education system and link education with its national development plans by emphasising scientific professional and technical studies [8]. Higher education in Iraq was advanced in the past, making it the best in the Middle East and the countries of the Arab Gulf. In 1982, Iraq won the UNESCO prize for the best illiteracy-free country, especially due to the endorsement of a law on free education [9]. Due to wars and the economic embargo imposed between 1991 and 2003, Iraq was distanced from the rest of the world, whilst government support for the teaching cadre weakened. As a result many academics and scientists in all fields and specialisations are left their universities, causing a brain drain away from the country.

According to a UNESCO report in 2003 [10], the poor level of international contact among Iraqi professors from 1991 onwards had an adverse impact on Iraqi universities, so that they were no longer comparable to international universities. As educational markets are becoming global nowadays, and the ability of the education system in Iraq to reach a global market will depend on changes in the systems, methods, curricula, and approaches.

Prior literature has recognised the relationship between KS and innovation [11], [12]. However, there is a lack of an empirical study to examine the impact of knowledge sharing processes namely donating and collecting on teaching staff's process innovation within developing countries specifically Iraq. This research could help the leaders in HEIs facing pressure to innovate, by enabling them to overcome the barriers that prevent the development of process innovation among their teaching staff, and by contributing to the development of management strategies that will work best for sector.

\section{KNOWLEDGE SHARING AND PROCESS INNOVATION}

Hislop [6] described Knowledge as a multidimensional concept, which consisting of data, information, skills, and experiences, which may be used in making decisions. Prior literature identified two types of knowledge tacit and explicit knowledge: Tacit knowledge is the personal and the intangible. It is embedded in the minds of people, accumulated through study, learning, and developed through conversations, and job training, this type is difficult to communicate [4]. Kim and Ju [2] found that members of staff 
in HEIs obtain this type of knowledge either by teaching courses or as a result of professional experience.

Explicit knowledge, on other hand, denotes knowledge that is articulated and captured, and has a more tangible format [13]. This type of knowledge is saved in documents and found in books, databases, policies, and regulations, therefore it is more common in the workplace and easy to share between individuals and organisations [14].

$\mathrm{KM}$ is a process of creating, disseminating, and applying organisational knowledge [15]. It has been noted that, when considering the application of KM initiatives, it is important to create a culture of knowledge sharing (KS) [6]. KS includes activities in which information, skills, and insights are exchanged among organisational members [15]. Yang and Farn [16] indicated that tacit KS among organisational members is one of the most important issues for KM success. It plays a large role in increasing the competitive advantage of the organisation and is a key to enhancing creativity [17]. Through KS, organisations can develop their skills, and competence, and increase their value [18]. Within educational institutions Daud and H. Abdul hamid [7] found that the exchanging of ideas, opinions, and experiences among faculty is critical for developing the learning process.

KS processes described as a two-dimensional process with members of staff sharing and exchanging their tacit and explicit knowledge. Daily interaction creates new knowledge through the process of knowledge exchange, donation, and collection [19]. Donating knowledge represents the willingness and eagerness of individuals in organisations to give and share their knowledge with others. It refers to the owner of knowledge, and includes listening, talking to others, and providing them with information so as to help them develop their self-knowledge and solve problems more quickly [20]-[22].

Knowledge collecting, on the other hand, refers to the recipient of knowledge who must consult colleagues through observation, listening or practising so as to encourage them to share their intellectual capital [19]. Lin [22] indicated that this process represents the acquisition of information and knowledge from internal and external sources.

These two processes of KS promote trust and mutual respect as well as facilitate the flow of people's knowledge assets to be capitalised for performance development [23]. It is argued that knowledge donating and collecting are linked with organisational learning because learning from others can help generate ideas and enhance organisational performance [24].

Organisations Today are increasingly focusing on innovation as a key factor in success and competitive advantage [25]. Innovative organisations have the capacity to improve individual and organisational performance and solve problems by effecting change and creating opportunities for them [26].

Du Plessis [27] stated that innovation refers to the creation of new thoughts, knowledge and ideas so as to make organisational outcomes possible. Tsai [28] claimed that process innovation can enhance the adaptability of organisations to environmental change and that they are present in organisations where problem solving and creativity thrive. Organisations with greater process innovation capabilities can achieve a better response from the environment and more easily build the capabilities needed to enhance organisational performance [29].

In higher education environments, innovation is important and it has been said that universities should rely on process innovation [30]. Albury [31] found that innovation has the ability to improve the learning outcomes and quality of the provision of education. Therefore, it is necessary to study this type of innovation within the higher education environment. This research defines process innovation as accepting, developing, and implementing new processes by developing and using new technology, good financial management, and the continuous improvement of skills.

Access to knowledge may help organisational members to come up with new ways to solve their problems and engage in further innovative activities [32]. Process innovation is shown to solve problems and improve performance [29].

Innovation depends on employees' knowledge, skills, and experience of value creation [33]. New knowledge is critical to developing innovative ideas for new process [29]. The knowledge-based view suggests that organisations need to exhibit knowledge creation but more importantly KS [4]. Since knowledge is embedded in the minds of the individuals, it is necessary for it to be shared among organisational members so that they can establish new routines and mental processes that may help them to solve their problems [14]. When organisational members share their tacit knowledge and convert it into explicit knowledge through collecting and donating, new knowledge and collective learning is generated, which in turn improves the stock of knowledge available to the organisation [14]. Through knowledge activities, employees can reconfigure and utilise existing knowledge in new ways so as to change and develop their tasks, which in turn generates new knowledge that can be used for process innovation [4].

Previous studies have reported that $\mathrm{KS}$ is a critical enabler for process innovation. For instance, Andreeva and Kianto [11] highlighted that knowledge creation can predict product, management, and marketing innovation. Zheng et al. [34] stated that KM includes acquisition, sharing, and application. They asserted that innovation and effectiveness is achieved in $\mathrm{KM}$ when $\mathrm{KS}$ is taken into consideration. Ling and Nasurdin [35] demonstrated that knowledge acquisition has a positive effect on product innovation, while the sharing and application of knowledge have no relationship with the latter. Kamasak and Bulutlar [23] found that knowledge collecting had more effect on exploitative and explorative innovation inside and outside departments than did donating knowledge in the context of industrial companies in Turkey. Cheng's [36] findings suggested that $\mathrm{KS}$ via interpersonal interaction and communities of practice is essential for improving teaching practice and the implementation of curricula.

Although previous studies have looked at the relationship between KS and innovation, few touch on knowledge processes and their impact on the teaching staff's process innovation, and there is a need for research addressing the practical difficulties of $\mathrm{KS}$ for process innovation within developing countries and particularly the Iraqi environment. Thus, this research suggests:

H1: knowledge donating will positively influence process innovation in Iraqi's public universities. 
H2: Knowledge collecting will positively influence process innovation in Iraqi's public universities.

\section{METHOD}

This research used quantitative method to examine the causal relationships between KS processes namely donating and collecting and process innovation. A self-administered questionnaire and the delivery-and-collection method of distribution were used. This technique is suitable for the Iraqi environment because the participants prefer to deal with paper work. Furthermore, direct contact (face-to-face) between the researcher and the respondents can induce a greater proportion of people to complete the questionnaire and allows the researcher to explain an ambiguous questions to the participants [37]. A five-point Likert scale ranging from $1=$ (strongly disagree) to $5=$ (strongly agree $)$ was used in this research. The questionnaire was translated into Arabic using the translation back-translation procedure.

$\mathrm{KS}$ in this paper is described as the exchange of knowledge and experiences regarding teaching operations and administrative issues among members of staff, through the donating and collecting of knowledge. The original instrument of Hooff and Weenen [19] consisted of 12 items which have been proved valid and reliable.

Eight items measure process innovation, reflecting the use of new approaches in service and delivery through the development and use of new technology, and the implementing of incentives and reward systems for members of staff. This measurement was developed from Perri [38] and Daft [39]. 400 questionnaires were sent to eight public colleges of which 252 were returned and usable for analysis.

\section{FINDINGS}

This research used structural equation modelling (SEM) with Analysis of Moment Structures (AMOS) 21 to examine the impact of knowledge donating and collecting on process innovation. SEM consists of two steps: Measurement model to evaluate the validity and reliability of the constructs and structural model to test the causal relationships among factors.

\section{A. Measurement Model}

The measurement model specifies the correlations between the factor loadings of the observed variables and the latent variables [40]. The validity of the measurement model depends on:1) establishing acceptable levels of goodness of fit for the model, and 2) finding specific evidence of construct validity [40]. To evaluate the validity of the measurement model, construct validity, consisting of convergent and discriminant validity was assessed through confirmatory factor analysis (CFA) using AMOS 21. The convergent validity was tested by investigating the factor loadings and the average variance extracted (AVE) measure which were deemed significant if they were 0.5 or higher [40], [41].

Three factors donating knowledge, collecting knowledge and process innovation were measured using 20 items. Reliability was assessed based on the Cronbach's alphas and Composite Reliability (CR), each of which should exceed 0.7
[40]. The results shown in Table I indicate that the convergent validity and internal reliability were satisfactory. All factor loadings and the CR and AVE were acceptable and significant.

TABLE I: MEASUREMENT MODEL

\begin{tabular}{|c|c|c|c|c|c|}
\hline Factor & Item code & Factor loading & $\alpha$ & AVE & CR \\
\hline \multirow{5}{*}{ Knowledge } & KD1 & 0.803 & 0.88 & 0.68 & 0.89 \\
donating & KD2 & 0.828 & & & \\
& KD3 & 0.790 & & & \\
& KD4 & 0.781 & & & \\
& KD5 & 0.882 & & & \\
\hline \multirow{5}{*}{ Knowledge } & KD6 & 0.854 & & & \\
& KC7 & 0.836 & 0.89 & 0.70 & 0.90 \\
& KC9 & 0.871 & & & \\
& KC10 & 0.847 & & & \\
& KC11 & 0.840 & & & \\
& KC12 & 0.795 & & & \\
Process & PI13 & 0.833 & & & \\
& PI14 & 0.775 & 0.88 & 0.67 & 0.89 \\
& PI15 & 0.860 & & & \\
& PI16 & 0.828 & & & \\
& PI17 & 0.813 & & & \\
& PI18 & 0.787 & & & \\
& PI19 & 0.723 & & & \\
& PI20 & 0.899 & & & \\
\hline
\end{tabular}

Note: $\mathrm{AVE}=$ average variance extracted, $\mathrm{CR}=$ Composite reliability, $\alpha=$ Cronbach's alpha

Discriminant validity was assessed using the criteria established by Fornell and Larcker [41]. According to them, the AVE should be greater than the squared correlations between the two constructs. The constructs for all of the data were found to be empirically distinct and the discriminant validity was confirmed statistically.

Table II displays the means and standard deviations. Additionally, it shows that the variances extracted from the constructs were greater than all of the squared correlations between the items:

TABLE II: DISCRIMINANT VALIDIT

\begin{tabular}{|l|c|c|c|c|c|}
\hline Construct & Mean & SD & 1 & 2 & 3 \\
\hline 1) Donating knowledge & 3.292 & 0.897 & 0.68 & & \\
\hline 2) Collecting knowledge & 3.544 & 0.860 & 0.285 & 0.70 & \\
\hline 3) Process innovation & 3.458 & 0.885 & 0.345 & 0.318 & 0.67 \\
\hline
\end{tabular}

Note: standard deviations $=\mathrm{SD}$

The levels of goodness of fit for the measurement model was found to be acceptable, as shown in Table III. There are two basic indices: (1) Absolute fit indices, this includes $\chi^{2} / d f$, and the root mean square error of approximation (RMSEA), and (2) the Model comparison indices. The fit indices used most often are the incremental fit measurement, which includes a normed fit index (NFI), a comparative fit index (CFI), and The Tucker-Lewis index (TLI) [40]:

TABLE III: GOODNESS OF FIT INDICES FOR MODEL

\begin{tabular}{|c|c|c|c|}
\hline FIT Indices & KS Process & $\begin{array}{c}\text { Process } \\
\text { Innovation }\end{array}$ & $\begin{array}{c}\text { Recommended } \\
\text { Criteria }\end{array}$ \\
\hline$X^{2} / \mathrm{df}$ & 1.523 & 1.970 & $\leq 2-5$ \\
\hline CFI & 0.978 & 0.953 & $\geq 0.90$ \\
\hline NFI & 0.967 & 0.973 & $\geq 0.90$ \\
\hline TLI & 0.977 & 0.953 & $\geq 0.90$ \\
\hline RMSEA & 0.043 & 0.033 & $<0.05-0.08$ \\
\hline
\end{tabular}




\section{B. Structural Model and Test Hypotheses}

The results from SEM supported the direct effect of knowledge donating and collecting on process innovation, and showed good fit indices: $X^{2}=147.661$ with $d f=103$, $X^{2} / d f=1.433, \mathrm{RMSEA}=0.035, \mathrm{NFI}=0.959, \mathrm{CFI}=0.979$ and TLI $=0.977$.

Table IV shows an effect size of KS on innovation is (0.569). H1 is concerned with the effect of knowledge donating on process innovation, while, $\mathrm{H} 2$ is concerned with the effect of knowledge collecting on process innovation. The path coefficients are significant at levels (0.534) and (0.605) respectively as shown in Table IV and Fig. 1 providing support for $\mathrm{H} 1$ and $\mathrm{H} 2$.

TABLE IV: RESULTS FROM SEM

\begin{tabular}{|c|c|c|c|}
\hline Hypothesis & Hypothesis path & Estimate & Results \\
\hline $\mathrm{H} 1$ & $\begin{array}{c}\text { K Donating } \rightarrow \\
\text { Process innovation }\end{array}$ & $0.534^{* *}$ & Confirmed \\
\hline $\mathrm{H} 2$ & $\begin{array}{c}\text { K Collecting } \rightarrow \\
\text { Process innovation }\end{array}$ & $0.605^{*}$ & Confirmed \\
\hline $\begin{array}{c}\text { H1 AND } \\
\text { H2 }\end{array}$ & $\begin{array}{c}\text { KS processes } \\
\text { Process innovation }\end{array}$ & $0.569^{* *}$ & Confirmed \\
\hline
\end{tabular}

Note: $P^{*}<0.05, P^{* *<} 0.01$

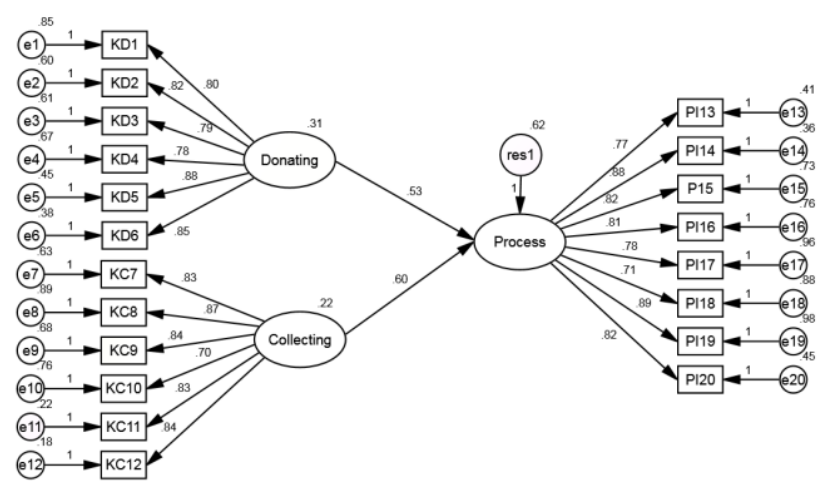

Fig. 1. Results of SEM.

\section{DISCUSSION}

The results of the SEM support the hypothesised relations between knowledge donating and collecting and process innovation ( $\mathrm{H} 1$ and $\mathrm{H} 2$ ) in public HEIs in Iraq. According to the knowledge-based view, knowledge is a valuable resource of organisations [4], [14]. Knowledge sharing refers to a two-dimensional process whereby organisational members share and exchange their tacit and explicit knowledge. Daily interaction creates new knowledge through the process of knowledge exchange, donation, and collection [19]. The purpose of donating knowledge is to see tacit knowledge become explicit and owned by the entire group. Meanwhile, collecting knowledge refers to consulting people and seeking knowledge out, which in turn improves the entire stock of knowledge available to the organisation [4], [14]. When knowledge is used, learning takes place, which in turn leads to changes of behaviour and then enhanced innovation [4].

The results of the current research found that teaching staff in Iraqi public HEIs are willing to donate and collect their skills, insights, expertise, information and notes both inside and outside of their own departments, which enables their universities to improve their process innovation by taking and developing training programmes and adopting new technology. Teaching staff in Iraqi HEIs exchanging their knowledge through forums, conferences, formal and informal meetings, seminars, and training programmes helps to diffuse innovations of process.

These findings support the assertions of previous studies such as those of Leung [42] and Cheng [43], who both indicated that promoting KS practice within an educational environment helps members of staff to discuss different ideas about teaching methods, experiences, and skills that could increase the effectiveness of teaching and learning performance, thus supporting process innovation. The findings are also congruent with Ferraresi et al. [44], who argued that KM processes, namely capturing, sharing, and application, can enhance innovation through the strategic orientation of the organisation.

\section{CONCLUSIONS}

This research examined the impact of KS processes on process innovation. The results found that KS processes as enablers for process innovation in Iraqi public HEIs. The research contributes to the theory on this subject and provides support for the knowledge-based view. It is empirically strengthen the relationship between KS processes and process innovation in Iraqi HE environment. These results give us a better understanding of how knowledge can lead to competitive advantage in HEIs. Managing knowledge and sharing it, as a strategic resource is one of the foundational weapons that enable universities to increase their competitive advantage and chances of survival. KS processes are the key factors to success in organisations. This means that innovation will emerge if HEIs in Iraq encourage and create a KS culture among their teaching staff in these knowledge-intensive institutions. Therefore, leaders should design strategies aimed at encouraging their teaching staff to engage in KS activities such as sessions, conferences, workshops, etc.

\section{APPENDIX: QUESTIONNAIRE ITEMS}

\begin{tabular}{|c|c|}
\hline FACTOR & ITEM \\
\hline \multirow{6}{*}{$\begin{array}{l}\text { Knowledge } \\
\text { donating }\end{array}$} & $\begin{array}{l}\text { Knowledge sharing with colleagues outside of my } \\
\text { department is considered normal }\end{array}$ \\
\hline & $\begin{array}{l}\text { Knowledge sharing among colleagues in my department } \\
\text { is considered normal }\end{array}$ \\
\hline & $\begin{array}{l}\text { When I have learned something new, I tell colleagues } \\
\text { outside of my department about it }\end{array}$ \\
\hline & $\begin{array}{l}\text { When they have learned something new, my colleagues } \\
\text { within my department tell me about it }\end{array}$ \\
\hline & $\begin{array}{l}\text { When I have learned something new regarding the } \\
\text { teaching profession, I tell my colleagues in my } \\
\text { department about it }\end{array}$ \\
\hline & $\begin{array}{l}\text { When they have learned something new, colleagues } \\
\text { outside of my department tell me about it }\end{array}$ \\
\hline \multirow{5}{*}{$\begin{array}{l}\text { Knowledge } \\
\text { collecting }\end{array}$} & $\begin{array}{l}\text { I share any information I have with colleagues within my } \\
\text { department when they ask for it }\end{array}$ \\
\hline & $\begin{array}{l}\text { Colleagues within my department share knowledge with } \\
\text { me, when I ask them for it }\end{array}$ \\
\hline & $\begin{array}{l}\text { Colleagues within my department share their skills with } \\
\text { me, when I ask them }\end{array}$ \\
\hline & $\begin{array}{l}\text { I share my skills with colleagues outside of my } \\
\text { department, when they ask me to }\end{array}$ \\
\hline & $\begin{array}{l}\text { I share my skills with colleagues within my department, } \\
\text { when they ask me to. }\end{array}$ \\
\hline
\end{tabular}




\begin{tabular}{|l|l|}
\hline \multirow{7}{*}{$\begin{array}{l}\text { I share information I have with colleagues outside of my } \\
\text { department when they ask me to }\end{array}$} \\
\hline \multirow{5}{*}{ Process } & $\begin{array}{l}\text { Our university is developing new training programmes } \\
\text { for staff members }\end{array}$ \\
\cline { 2 - 3 } & $\begin{array}{l}\text { Our university encourages teamwork and relationships } \\
\text { between staff members }\end{array}$ \\
\cline { 2 - 3 } & $\begin{array}{l}\text { Our university implements an incentive system (i.e. } \\
\text { higher salaries, bonuses,--) to encourage members of } \\
\text { staff to come up with innovative ideas }\end{array}$ \\
\cline { 2 - 3 } & $\begin{array}{l}\text { Our university often develops new technologies (internet, } \\
\text { databases,--) to improve the educational process }\end{array}$ \\
\cline { 2 - 3 } & $\begin{array}{l}\text { Our university often uses new technologies to improve } \\
\text { the educational process }\end{array}$ \\
\cline { 2 - 3 } & $\begin{array}{l}\text { New multimedia software is implemented by this } \\
\text { university for educational purposes and administrative } \\
\text { operations }\end{array}$ \\
\cline { 2 - 3 } $\begin{array}{l}\text { This university implements a reward system (i.e. } \\
\text { promotions, thank yous,--) for members of staff to } \\
\text { encourage them to come up with innovative ideas }\end{array}$ \\
\hline & $\begin{array}{l}\text { Our university is trying to bring in new equipment (i.e. } \\
\text { computers) to facilitate educational operations and work } \\
\text { procedures }\end{array}$ \\
\hline
\end{tabular}

\section{REFERENCES}

[1] V. Mathew, "Service delivery through knowledge management in higher education," Journal of Knowledge Management Practice, vol. 11, no. 3, pp. 1-14, 2010.

[2] S. Kim and B. Ju, "An analysis of faculty perceptions: Attitudes toward knowledge sharing and collaboration in an academic Institution," Library and Information Science, vol. 30, no. 4, pp. 282-290, 2008.

[3] O. Maponya, "Fostering the culture of knowledge sharing in higher education," South African Journal of Higher Education, vol. 19, no. 5 , pp. 900-911, 2005.

[4] G. V. Kroh, I. Nonaka, and L. Rechsteiner, "Leadership in organizational knowledge creation: A review and framework," Journal of Management Studies, vol. 49, no. 1 pp. 240-277, 2012.

[5] A. Antunen, "Knowledge processing capabilities and innovation performance: An empirical study," Journal of Innovation Management, vol. 8, no. 3, pp. 336-349, 2005.

[6] D. Hislop, Knowledge Management in Organisations, $3^{\text {rd }}$ ed. UK: Oxford University Press, 2013.

[7] S. Daud and H. Abdulhamid, "Successful knowledge sharing in private higher institutions education: Factors and barriers," presented at the Knowledge Management International Conference and Exhibition, K. L., Malaysia, 2006

[8] A. Sikhi, Study the System in Iraq, Report, Baghdad: Higher Education Press, 2008.

[9] Division of educational policies and strategies, Iraq, Education in Transition Needs and Challenges, United Nations Educational Scientific and Cultural Organisation (UNESCO), Paris, France, 2004, pp.1-151.

[10] Division of educational polices and strategies, Situation Analysis of Education in Iraq, United Nations Educational Scientific and Cultural Organisation (UNESCO), Paris, France, 2003, pp 1-127.

[11] T. Andreeva and A. Kianto, "Knowledge processes, knowledge-intensity and innovation: A moderated mediation analysis," Journal of Knowledge Management, vol. 15, no. 6, pp. 1016-1034, 2011.

[12] C. Chen, J. Huang, and Y. Hsiao, "Knowledge management and innovativeness: The role of organizational climate and structure," International Research Journal of Manpower, vol. 31, no. 8, pp. 848-870, 2010.

[13] S. Yahya and W. Goh, "Managing human resources toward achieving knowledge management," Journal of Knowledge Management, vol. 6, no. 5, pp. 457-468, 2002.

[14] I. Nonaka, G. V. Krogh, and S. Voelpel, "Organizational knowledge creation theory: Evolutionary paths and future advances,' Organization Studies, vol. 27, no. 8, pp. 1179-1208, 2006.

[15] S. Massa and S. Tsesta, "A knowledge management approach to organisational competitive advantage: Evidence from the food sector," European Management Journal, vol. 27, pp.129-141, 2009.

[16] S. Yang and C. Farn, "Social capital, behavioural control, and tacit knowledge sharing - A multi-informant design," International Journal of Information Management, vol. 29, no. 3, pp. 210-218, 2009.

[17] J. Saenz, N. Aramburu, and O. Rivera, "Knowledge sharing and innovation performance: A comparison between high-tech and low-tech companies," Journal of Intellectual Capital, vol. 10, no. 1, pp. 22-36, 2009.

[18] B. Renzl, "Trust in management and knowledge sharing: The mediating effects of fear and knowledge documentation," The International Journal of Management Science, vol. 36, no. 2, pp. 206-220, 2008.

[19] V. Hooff and F. Weenen, "Committed to share: Commitment and CMC use as antecedents of knowledge sharing," Knowledge and Process Management, vol. 11, no. 1, pp. 13-24, 2004.

[20] F. Reid, "Creating a knowledge sharing culture among diverse business units," Employment Relations Today, vol. 30, no. 3, pp. 43-49, 2003.

[21] J. Cumming, "Work groups structural diversity and knowledge sharing in a global organization," Management Science, vol. 50, no. 3, pp. 352-364, 2004.

[22] H. Lin, "Knowledge sharing and firm innovation capability: An empirical study," International Journal of Manpower, vol. 28, no. 3/4 pp. 315-337, 2007.

[23] R. Kamasak and S. Bulutlar, "Influence of knowledge sharing on innovation," European Business Review, vol. 22, no. 3, pp. 306-317, 2010.

[24] I. Seba, J. Rowlay, and S. Lambert, "Factors affecting attitudes and intentions towards knowledge sharing in the Dubia police force," International Journal of Information Management, vol. 32, no. 4, pp. 372-380, 2012.

[25] J. Tidd and J. Bessant, Managing Innovation: Integrating, Technological, Market and Organizational Change, 4th ed. London, UK: John Wiley \& Sons Limted, 2011.

[26] M. Schiling, Strategic Management of Technological Innovation, $3^{\text {rd }}$ ed. New York: McGraw-Hill/Irwin, 2010.

[27] M. D. Plessis, "The role of knowledge management in innovation," Journal of Knowledge Management, vol. 11, no. 4, pp. 20-29, 2007.

[28] W. Tsai, "knowledge transfer in intra-organizational network: Effects of network position and absorptive capacity on business unit innovation and performance," Academy of Management Journal, vol. 44, no. 5, pp. 996-1004, 2001.

[29] D. Jimenez and R. Vall, "Innovation, Organizational Learning and performance," Journal of Business Research, vol. 64, no. 4, pp. 408-417, 2011.

[30] K. Jaskyte. (2004). Organizational culture and innovation in non-profit $\begin{array}{lll}\text { organizations. } & \text { [Online]. Available: }\end{array}$ http://kijaskte.myweb.uga.edu/nsf/nsfAnnualReportI.pdf

[31] D. Albury, "Fostering innovation in public services," Public Money \& Management Journal, vol. 25, no. 1, pp. 51-56, 2005.

[32] S. Rodan and C. Galunic, "More than network structure: How knowledge heterogeneity influences managerial performance and innovativeness," Strategic Management Journal, vol. 25, no. 6, pp. 541-562, 2004.

[33] Z. Wang and N. Wang, "Knowledge sharing, innovation and firm performance," Expert Systems with Applications, vol. 39, no. 10, pp. 8899-8908, 2012.

[34] W. Zheng, B. Yang, and G. Mclean, "Linking organizational culture, structure, strategy, and organizational effectiveness: Mediating role of knowledge management," Journal of Business Research, vol. 6, no. 7, pp. 763-771, 2009.

[35] T. Ling and A. Nasurdin, "The influence of knowledge management effectiveness on administrative innovation among Malaysian manufacturing firms," Asian Academy of Management Journal, vol. 15 , no. 1 , pp. 63-77, 2010.

[36] C. Cheng, "Cultivating communities of practice via learning study for enhancing teacher learning," Journal of Educational Policy, vol. 6, no. 1, pp. 81-104, 2009.

[37] M. Saunders, P. Lewis, and A. Thornhill, Research Methods for Business Students, 5th ed. UK: Pearson education Limited, 2009.

[38] Perri 6, "Innovation by nonprofit organizations: Policy and research issues," Nonprofit Management and Leadership, vol. 3, issue 4, pp. 397-414, 1993.

[39] R. Daft, "Organizational innovation," Academy of Management Journal, vol. 21, no. 2, pp. 193-210, 1978.

[40] J. Hair, W. Black, and R. Anderson, Multivariate Data Analysis: A Global Perspective, $7^{\text {th }}$ ed. US: Pearson Prentice Hall, 2010.

[41] C. Fornell and D. Larcker, "Evaluating structural equation models with unobservable variables and measurement error," Journal of Marketing Research, vol. 18, no. 1, pp. 39-50, 1981.

[42] H. Leung, "Critical factors of implementing knowledge management in school environment: a qualitative study in Hong Kong," Research Journal of Information Technology, vol. 2, no. 2, pp. 66-80, 2010. 
[43] E. Cheng, "Knowledge strategies for enhancing school learning capacity," International Journal of Educational Management, vol. 26 , no. 6 , pp. $577-592,2012$.

[44] A. Ferraresi, C. Santos, and R. Frega, "Knowledge management and strategic orientation: Leveraging innovativeness and performance," Journal of Knowledge Management, vol. 16, no. 5, pp. 688-701, 2012.

Sawasn J. Al-Husseini is currently a lecturer at Middle Technical University, Institute of Administration Rusafa, Baghdad, Iraq and a senior member at International Economics Development Research Centre (IEDRC).

Sawasn Al-Husseini did her B.Sc degree in business administration at Baghdad University and M.Sc from Al-Mustansiriya University, Iraq. She received her $\mathrm{PhD}$ degree in management information systems (MIS) from Plymouth University, School of Management, Plymouth, UK

Dr. Al-Husseini's publications are related to the innovation, leadership style, knowledge management and knowledge sharing, she has more than 18 papers published at national and international journals and conferences.

Ibrahim Elbeltagi is a lecturer in information and knowledge management at the School of Management, University of Plymouth, UK. As the business information management systems programme manager, he is responsible for modules in world of business, information and decision making, electronic society, innovation and project management, business project and research methods and the director of Studies of the PhDs. Ibrahim Elbeltagi did his B.Sc. and M.Sc degrees in marketing at Mansoura University, Egypt and $\mathrm{PhD}$ in management information systems from Huddersfield University Business School, UK. His publications are related to electronic commerce, e-government, adoption of ICT, information systems in developing countries, social networking, and knowledge management. He has more than 30 journal and conferences papers published in national and international journals and conference.

Talib A. Dosa is currently an assistant professor and the general director of the Information and Researches Office at Immigration and Displacement Ministry, Iraq. Talib Dosa did his B.Sc. and M.Sc in business administration from Al-Mustansiriya University, Baghdad, Iraq.

His publications are related to strategic change, innovation, leadership style and knowledge management. He has more than 22 papers published at national and international journals and conferences. 